\title{
Students and Parents' Perceptions toward English Online Learning during Corona Virus Pandemic
}

\author{
Nihta Liando $^{1 *}$, Noldy Pelenkahu², Steve Mongkaren ${ }^{3}$ (D) \\ ${ }^{1,2,3}$ Manado University, Manado, Indonesia
}

\section{A R T I C L E I N F O}

Article history:

Received April 02, 2021

Revised April 03, 2021

AcceptedMay 05, 2021

Available online May 25, 2021

Kata Kunci:

Pembelajaran Daring, Metode

Tradisional, Persepsi

Keywords:

Online Learning, Traditional

Method, Perception

DOI:

http://dx.doi.org/10.23887/jpbi.v9 i1.35049

\section{A B S T R A C T}

E-learning dramatically changes the learning process. As a result, both teachers and students have to work hard to adapt to the process. In response to these changes, this study aims to analyze the perceptions of junior high school, senior high school, and parents regarding online learning. This study involved 44 parents, 24 junior high school students, and 20 high school students. Data were collected using two questionnaires. The data collected were analyzed quantitatively in the form of percentages. The results of data analysis show that junior high school students use computers/devices for online learning activities; however, they consider traditional methods (live class meetings) to be more appropriate than online learning. (2) High school students also use their computers/devices for online learning and have full support from their teachers, but they prefer traditional methods. They consider traditional methods more effective than online learning, and (3) parents prefer traditional methods over online learning. Therefore, teachers are advised to be creative in teaching online; parents are expected to continue to control their students' online learning. More research is needed so that more information about online learning can be obtained. This is an open access article under the CC BY-SA license.
Copyright (C) 2021 by Author. Published by Universitas Pendidikan Ganesha. This is an open access article under the CC BY-SA license.
Copyright (C) 2021 by Author. Published by Universitas Pendidikan Ganesha.

\begin{abstract}
E-learning secara dramatis mengubah proses pembelajaran. Akibatnya, baik guru maupun siswa harus bekerja keras untuk beradaptasi dengan proses tersebut. Menanggapi perubahan tersebut, penelitian ini bertujuan untuk menganalisis persepsi SMP, SMA, dan orang tua mengenai pembelajaran daring. Penelitian ini melibatkan 44 orang tua siswa, 24 siswa SMP, dan 20 siswa SMA. Data dikumpulkan dalam bentuk persentase. Hata yang dikumpulkan dianalisis secara kuantitatif menggunakan komputer/gawai untuk kegiatan pembelajaran daring; namun, mereka menganggap metode tradisional (pertemuan kelas langsung) lebih tepat daripada pembelajaran daring; (2) siswa SMA juga menggunakan komputer/gawai mereka untuk pembelajaran daring dan mendapat dukungan penuh dari guru mereka, tetapi mereka lebih memilih metode tradisional. Mereka menganggap metode tradisional tebih efektif daripada pembelajaran daring; dan (3) orang tua lebih menyukai metode tradisional daripada pembelajaran daring. Oleh karena itu, guru disarankan untuk eatif dalam mengajar secara daring; orang tua diharapkan untuk terus mengontrol pembelajaran online siswa mereka. Diperlukan lebih banyak penelitian lagi agar lebih banyak informasi tentang pembelajaran daring dapat diperoleh.
\end{abstract}

\section{INTRODUCTION}

To most teachers and students, E-learning learning is something new. E-learning, as it is often called, has dramatically changed the manner and process of delivering learning courses and imparting necessary knowledge (Garbin et al., 2020; Rahmat, 2020). Consequently, both teachers and students have to work hard to adapt to the process. On the one hand, e-learning has opened a new and improved path of learning (Almaiah et al., 2020; Elfeky et al., 2020). At the university level, online learning has been applied widely nowadays. In some other parts of the world, especially in developed and some developing countries online learning has been students' daily activity (Mailizar et al., 2020; Ramkissoon et al., 2020). In Indonesia, this has been used by leading universities. When using distance learning, students work online at home while the lecturer or teacher assigns work and checks in digitally. Studies show that technology integration in the higher and professional education world provides learners with an increased opportunity to control the learning process, as they can access learning materials with ease and convenience (Amiti, 2020; Ja'ashan, 2020).

There have been a number of studies on parents and family support in students learning (Liando, 2012; Oostin, 2018). In particular, studies on parents' understanding of, support for, and concerns about E-learning in countries where e-learning has been intensively used indicate that e-learning has some advantages for students. Primary school students, parents, and teachers have positive perceptions toward the use of computers, the Internet, and social networking sites (Mailizar et al., 2020; Ramkissoon et al., 2020). E-learning can improve the quality of students learning according to parents' perception by providing them a wide variety of accessibility of learning 
materials (Amiti, 2020; Ja'ashan, 2020). The students are not limited or restricted in any manner, regarding course materials, availability of faculty members, accessibility, and time-related issues.

In contrast with the above-mentioned findings, previous research found that the parents generally had negative beliefs about the values and benefits of online learning and preferred traditional learning settings (Dong et al., 2020). They tended to resist and even reject online learning for three key reasons: the shortcomings of online learning, young children's inadequate self-regulation, and their lack of time and professional knowledge in supporting children's online learning. Similarly, previous research found that overall, $77 \%$ of students have negative perceptions towards e-learning and concluded that students did not prefer e-teaching over face-to-face teaching during the lockdown situation (Abbasi et al., 2020). Administration and faculty members should take necessary measures for improving e-teaching for better learning during the lockdown. The implementation of online learning programs was a very great idea and is supported by the majority of the sampled students. However, what came up during the research is the high cost of participating in online learning. Last but not least, the study discovered that internet connectivity is limited. Briefly, parents tend to have both and negative-positive perceptions toward the use of e-learning.

Similar studies were also conducted to obtain information about students' perceptions toward e-learning. Before the coronavirus pandemic, the previous research found that the students accepting the E-learning system with the desire to use it in a more advanced manner (Eze et al., 2018; Weng et al., 2018). The majority of the students think e-learning is an innovative idea and must be encouraged (Amalia \& Brata, 2018; Soni et al., 2018). Students are deeply aware of the changes brought over by digital technologies, by their impact on the learning process. Using this type of educational technology in elementary, junior, and high school education in Indonesia, on the one hand, is a new practice that makes certain requirements for the material, technical, organizational, and professional attainment level of information technology (Astuti et al., 2021; Bastemur \& Bastemur, 2015). On the other hand, the school community does not have the necessary competencies and range of tools to implement and use distance learning technologies. This dictates the need to study the condition of all the components listed above, as well as the readiness of the school community: teachers, dedicated specialists, administrative personnel, students, and their parents to implement and use distance learning technology.

Previous research findings stated that online learning could facilitate student learning (Khalil, 2018; Parker et al., 2021). Other research findings also state that online learning affects students to learn independently (Mpungose, 2021). It can be concluded that online learning can have a positive impact on students. There is no study regarding students' and parents' perceptions of online English learning during the Covid-19 pandemic. This study aimed to analyze the perceptions of students and parents towards online English learning during the Covid19 pandemic. It is hoped that online learning can help students in independent learning.

\section{METHOD}

This study falls into the category of survey research or self-report study. In a survey study, the researcher infers information about a population of interest based on the responses of a selected sample drawn from that population; preferably, the sample is either purposely selected or randomly selected. The information is solicited from individuals using, for example, questionnaires, interviews, or standardized attitude scales (Gay et al., 2012). In this study there are two groups of population. One is parents, the other one is students. They live in the resort kepolisian housing complex in Amurang. In this study, two questionnaires were used to collect data to answer the research questions. The first questionnaire was used to assess SMP and SMA students' perceptions; the second one was used for assessing their parents' perceptions. The questionnaire for parents was adopted from previous research studies conducted by (Khan et al., 2021). The one for students was self-developed. The questionnaires were translated into bahasa Indonesia before they were used to collect the data. The data collected using questionnaires were quantitatively analysed in percentage.

\section{RESULT AND DISCUSSION}

\section{Result}

There were four indicators in the questionnaire assessing online learning. The four indicators are the use of online, teacher support, interaction/group work, and students' preferences related to online learning. This questionnaire was distributed to both SMP and SMA students. This analysis deals first with data from SMP respondents. The data relating to SMP Students' use of computer/gadgets for online learning, showed that (1) majority of students $(96 \%)$ always or usually used the internet (email and Whatsapp) to send their assignments to their teachers; (2) almost all of them (88\%) always or usually asked their teachers questions to clarify instructional materials or tasks they were assigned to study or do; (3) majority of the students (92\%) used their computers or hand-phones to get more information about the instructional materials or tasks given from other sources; (4) they $(88 \%)$ always/usually use their computer or hand-phone to read the instructional material/tasks they were assigned 
to read; (5) only a small number of them (3 respondents/12\%) used their computer to find out how their tasks assessed by their teachers. In short, the majority of the respondents always/usually used their computers or handphone for learning purposes.

The data that dealt with teacher's support showed that (1) majority of the respondents (88\%) indicated that their teachers always/usually willingly responded to their questions asked; (2) 95 respondents revealed that their teachers willingly helped them when they needed their help; (3) the teachers also usually/always immediately responded to their questions as indicated by $83 \%$ of the respondents; (4) $84 \%$ of the respondents indicated that their teacher always/usually motivated them to participate in online learning; (5) 87\% respondents revealed that their teachers usually/always answered their question without giving more explanation about what was asked; (6) $83 \%$ respondents showed that their teachers usually/always provide necessary inputs in relation to the instructional materials/tasks that were given; and (7) 96\% respondents indicated that their teachers were easily contacted when the respondents needed their help. In brief, the teachers were very helpful and always/usually a step behind when the respondents needed their help.

Data that dealt with student interaction and cooperation show that (1) majority of the respondents (96\%) revealed that they were able and willing to cooperate with their classmates; (2) 88\% of respondents tended to share their work/tasks with their classmates; (3) $92 \%$ respondents shared information they had with their classmates; (4) $83 \%$ respondents discussed their tasks or instructional materials received from their teachers with their classmates; (5) $96 \%$ of the respondents worked collaboratively with their friends, and (6) $96 \%$ respondents participated in group activities. Only a few of them, maximally 3 respondents or $12 \%$ rarely interacted or cooperated with their classmates online. In short, the respondents used their computers to interact, discuss, worked together with their classmates, and shared information among them.

The data relating to the respondents' online learning preferences showed that (1) all the respondents $(100 \%)$ strongly considered classroom meeting more effective than online learning; (2) all of the respondents $(100 \%)$ considered online learning effective if it was accompanied with written instructional materials; and (3) they strongly agreed that instructional materials were easier to understand in classroom meeting than in online learning. In brief, SMP students living in Resort Kepolisian housing complex in Amurang preferred classroom meetings to online learning through computer/handphone, because it was more effective and instructional materials were easier to understand.

In connection with the use of computer/handphone, the data showed that (1) 95\% of SMA respondents made use of computer/handphone to send their tasks or assignments to their teachers through email or WhatsApp; (2) $80 \%$ of them made use of the devices to ask their teachers questions; (3) $85 \%$ respondents used the devices to search for more information about the instructional materials given by the teachers; (4) $85 \%$ of the total respondents used the devices to read teacher's notes related to the instructional materials/tasks given; and (5) 70\% rarely or never used the devices to check how their teachers assessed the assignment sent to them. In brief, the majority of the respondents, minimally $80 \%$, used computers/handphones to support their online learning. $70 \%$ of them rarely used the devices to check how their teachers assessed the task/assignments sent to them.

Concerning teacher support, It was revealed that (1) as with those reported by SMP respondents, $85 \%$ of SMA respondents indicated that their teachers always/usually willing to respond to questions put forward by their students; (2) 95\% always/usually helped the respondents identify problems faced in their study; (3) 90\% indicated that their teachers always/usually responded to their questions immediately after they were put forward; (4) $75 \%$ usually were willing to respond to the students' question; (5) $80 \%$ of the existing respondents indicated that their teachers always/usually provided the answers to their questions; (6) $85 \%$ respondents indicated that their teachers always/usually provided more input or explanations to help them learn the instructional materials or do the tasks assigned to them; and (7) $85 \%$ showed that always/usually their teachers were easily contacted. In sum, the data indicated that their teachers strongly supported their online learning.

As with those at SMP, the data showed that SMA students used computers or handphones to interact or cooperate with their classmates. The data show that (1) $80 \%$ of the SMA respondents willingly used and had the intention to interact or cooperate with their classmates; (2) $80 \%$ of them used computer/handphone to compare their tasks/work with tasks/work of their classmates; (3) $85 \%$ of the respondents shared information they had with their classmates; (4) $85 \%$ discussed their learning materials/tasks with their friends; (5) $85 \%$ worked collaboratively with their classmates; and (6) 80\% considered group working as an inherent part of their online learning. In brief, the majority of the SMA respondents willingly interacted, collaborated, discussed, and shared information related to their online learning materials/tasks with their classmates. Only a few of them or less than $20 \%$ rarely involved in group interaction or cooperation.

The data on SMA students' preferences indicated that (1) $100 \%$ of respondents always/usually believed that direct classroom meeting is more effective than online learning through computer/handphone; (2) although $70 \%$ of respondents suggested that online learning plus written instructional materials make learning better than it was without written materials, $30 \%$ of the respondents seemed not sure about its effectiveness; and 
(3) $100 \%$ SMA respondents fully confident that instructional materials presented in direct classroom meeting are better understood than those presented online.

As pointed out before, the questionnaire used to collect data related to parent perception on online learning is different from that used for students. The questionnaire consisted of 2 indicators, namely perception about online classes and teachers taking online classes. The data on parents' perceptions about online learning showed that some parents agreed with some of the statements dealing with online classes; some others were neutral or disagree with the statements put forward. Concerning item No. 1, for example, most of the parent respondents did not consider it effective as most of the respondents strongly disagreed (34\%) and disagreed (39\%) with the statement; 4 (or 9\%) respondents were neutral whereas 3 (or $7 \%$ ) and $5(11 \%)$ respondents strongly agreed and agreed respectively. In item no.2, the traditional method of studying or direct classroom meetings is considered to be more effective than online learning. Of 44 parent respondents, 17 respondents (39\%) strongly agreed, 16 or $36 \%$ respondents agreed, 3 or $7 \%$ neutral, and 8 or $18 \%$ respondents disagree. This indicated that the majority of the respondents considered the traditional method more favorable or fruitful than online learning.

In item no. 3 , the respondents were required to put forward their opinions about the statement 'Student still feel connected with the teacher'. Of all the respondents, 12 (or 27\%) strongly agreed that students still felt connected with their teacher; 16 or $36 \%$ agreed; 6 respondents or $16 \%$ neutral, and 10 or $23 \%$ thought that students did not feel connected with their teachers. In other words, although $63 \%$ of respondents thought that students still maintained their relationship with their teachers, $37 \%$ of respondents were in doubt whether teacherstudent relationships were still as close as they were before the pandemic. Item No. 4 requires parent respondents their opinions about the statement "Students miss their classroom classes' (due to the pandemic). Of 44 respondents, 17 respondents (or 39\%) strongly agreed and 22 others (50\%) agreed that the students missed their class. Only 2 respondents $(5 \%)$ were neutral and 3 or $7 \%$ disagreed. This indicated that the majority of the respondents worried about their sons/daughters' academic progress.

In item no. 5, the respondents were to give their opinions about the statement: Practical subjects like science, Mathematics, and English need a face-to-face method of teaching. The majority of e respondents (20 or $45 \%$ strongly agreed and 21 or $48 \%$ agreed) indicated that these practical subjects can only be effectively learned if taught face-to-face in regular class meetings. It seemed that they were so worried about their sons/daughters' academic progress in these subjects. The respondents were also required to give their opinion about the statement: My child enjoys online classes (item no. 6). The data obtained indicated that 7 respondents (16\%) were neutral, 13 respondents (30\%) disagreed, and 18 others (41\%) strongly disagreed. The rest, 6 respondents (14\%) strongly agreed or agreed. The data indicated that most of the respondents revealed that their sons/daughters did not enjoy online learning.

The respondents were to respond to the statement: Creativity is lost in online classes (item 7). The data collected indicated that 17 respondents (39\%) strongly agreed with the statement; 16 respondents $(36 \%)$ agreed, 6 or 14\% neutral, and the rest, 5 respondents, disagreed and strongly disagreed. this, again, indicated that the respondents were worried about the effectiveness of online learning. The last item in this section required the respondent to comment on: Online classes are value for money. The data obtained indicated that of 44 respondents, 9 (or 39\%) strongly agreed, 15 (or 34\%) agreed, 10 (or 23\%) neutral, 10 (or 23\%) disagreed, and 5 (11\%) strongly disagreed. The data seemed to indicate that their sons/daughters' academic progress was not a matter of money or how much parents had to spend.

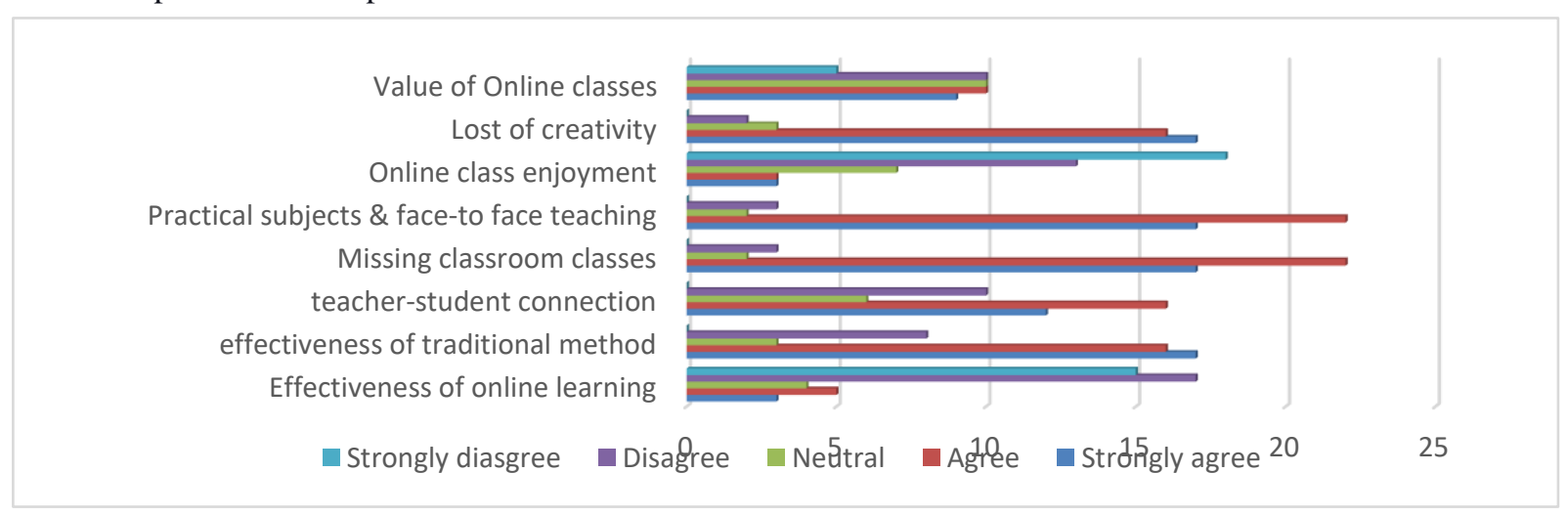

Figure 1. Parents' perceptions about online classes

In the next section, parents were given five statement to comment. This section dealt with their perceptions related to taking online classes. Concerning item 9, for example, Teachers make extra efforts in online classes, the respondents provided the following responses: 16 (or 36\%) respondents strongly agreed that since it is new to most them, teachers needed to work a bit harder; 21 (or 48\%) respondents agreed that extra work was 
needed in online class; 3 (or 7\%) respondents were neutral in this case, while the rest, 4 (or $9 \%$ ) respondents strongly disagreed. Briefly, majority of the respondents thought that online class needed extra work from the teacher.

Item 10 is For teachers, online teaching is a simple job. The respondents gave the following responses: 5 (or $11 \%$ ) and 7 (or 16\%) respondents strongly agreed and agreed respectively that basically teaching online classes was a simple job. In their opinions, the teacher just sat in from o his computer and delivered the material. The rest, 7 (or 16\%) respondents were neutral, 14 (or 32\%) disagreed, and 11 (or 25\%) strongly disagreed. Those who were neutral, an, disagreed and strongly disagreed considered teaching online class was not as simple as sitting in front of computer and delivered the instructional material. It was more than that. Item 11, It is challenging job for the teachers, as it is tedious. The data collected indicated that 6 (or 14\%) and 8 (or 18\%) respondents strongly agreed and agreed with the idea that teaching online class was something boring. the rest, 12 (or $27 \%$ ) were neutral, 10 (or 23\%) disagreed, and the rest, 8 (or 18\%) respondent strongly disagreed. Those who were neutral and disagreed considered teaching online class as something interesting. It is boring and monotonous if the teacher just sat in front of the computer and delivered the materials.

Item 12, Online teaching is extra work for the teacher. The data obtained indicated that 3 (or $7 \%$ ) and 5 (or $11 \%$ ) respondents considered teaching online class was as extra work. The rest, 6 or (14\%) respondents were neutral, 18 (41\%) disagreed, and 15 (or 34\%) strongly disagreed. It seemed that those who were neutral and disagreed considered teaching online classes was not extra work. Teaching online class was the main job of the teacher and was similar to teaching in regular class. Item 13, Teachers are more trained for classroom teaching. The data obtained showed that 19 or $43 \%$ ) and 21 (or $48 \%$ ) respondents strongly agreed and agreed respectively that teachers were more trained for classroom teaching. the rest, $1(2 \%)$ was neutral, and $3(7 \%)$ disagreed. In other words, the respondents indicated that teachers were not prepared for online class. They were prepared for direct classroom instruction. They were to teach online class due to the pandemic.

\section{Discussion}

Based on the data findings above, First concerning, responses from SMP students, it can be said that concerning computer/handphone use, majority of the respondents always/usually used their computers or handphone for learning purposes. Technology can support the learning process (Fakhruddin et al., 2019; MacLachlan et al., 2018). During online leaning, the teachers were very helpful and always/usually a step behind when the respondents needed their help. Teachers who help students while studying will make it easier for students to understand the subject matter (Brandmiller et al., 2020; Márquez-García et al., 2020). They used their computers to interact, discuss, worked together with their classmates, and shared information among them. Most of them preferred classroom meeting to online learning through computer/handphone, because it was more effective and instructional materials were easier to understand.

First, as with those from SMP, SMA students in the housing complex in Amurang used their computer/handphone to support their online learning. Mobile phones can also be used as a learning tool for students (Sophonhiranrak, 2021; Sunismi, 2015). They were fully supported by their teachers in their online learning. Furthermore, majority of the SMA respondents willingly interacted, collaborated, discussed and shared information related to their online learning materials/tasks with their classmates. Discussing and interacting in learning is also one way that makes learning fun (Edriati et al., 2015; Lailiyah \& Wulansari, 2017). Only a few of them or less than $20 \%$ rarely involved in group interaction or cooperation. They were fully confident that instructional materials presented in direct classroom meeting were better understood than those presented online. To them, classroom meeting was more effective than online learning.

Second, as with their sons/daughters, parents living in the housing complex were not satisfied with online learning. Online learning was considered not effective by majority of parent respondents. According to them, traditional method was more favorable or fruitful than online learning. In addition, online learning made students did not feel connected with their teachers, and that they were worried about their sons/daughters' academic progress, because their sons/daughters did not enjoy it. That is why they were so worried about the effectiveness of online learning. Some parents considered online learning expensive, but to some, online learning was not a matter of money. Concerning parents' perceptions about teachers taking online classes, it can be briefly said that majority of the respondents thought that online class needed extra work from the teacher. They considered online class or online learning was not a simple job, because teachers were not trained for online learning. They were trained for classroom teaching. Online learning needed creativity on the part of the teachers in order not to make it tedious (Ferri et al., 2020; Zhu et al., 2020). It was boring and monotonous only if the teacher just sat in front of the computer and delivered the materials (Satyawan et al., 2021; Stover et al., 2016). 


\section{CONCLUSION}

The majority of the SMP respondents used their computers or hand-phones for learning purposes. They used their computers to interact, discuss, worked together with their classmates, and shared information among them. However, they prefer classroom meeting to online learning, because it was more effective and instructional materials were easier to understand. The SMA students used their computer/mobile phone to support their online learning with full support from their teachers. Majority of the SMA respondents willingly interacted, collaborated, discussed and shared information related to their online learning materials/tasks with their classmates. However, they preferred traditional teaching to online learning. The parents were not satisfied with online learning. To them, online learning ineffective was ineffective compared to traditional method of teaching.

\section{REFERENCES}

Abbasi, S., Ayoob, T., Malik, A., \& Memon, S. I. (2020). Perceptions of Students Regarding E-Learning during Covid-19 at a Private Medical College. Pak J Med Sci, 36. https://doi.org/10.12669\%2Fpjms.36.COVID19S4.2766

Almaiah, M. A., Al-Khasawneh, A., \& Althunibat, A. (2020). Exploring the critical challenges and factors influencing the E-learning system usage during COVID-19 pandemic. Education and Information Technologies, 25(6), 5261-5280. https://doi.org/10.1007/s10639-020-10219-y

Amalia, F., \& Brata, A. H. (2018). Analisis Tingkat Penerimaan Sistem E-Learning menggunakan Blog Gratis sebagai Alternatif Media Pembelajaran pada Guru. Jurnal Teknologi Informasi Dan Ilmu Komputer, 5(3), 335. https://doi.org/10.25126/jtiik.201853640

Amiti, F. (2020). Synchronous and asynchronous E-learning. European Journal of Open Education and ELearning Studies, 5(2), 60-70. https://doi.org/10.46827/ejoe.v5i2.3313

Astuti, M., Arifin, Z., Mutohhari, F., \& Nurtanto, M. (2021). Competency of Digital Technology: The Maturity Levels of Teachers and Students in Vocational Education in Indonesia. Journal of Education Technology, 5(2), 254-262. https://doi.org/10.23887/jet.v5i3.35108

Bastemur, S., \& Bastemur, E. (2015). Technology Based Counseling: Perspectives of Turkish Counselors. Procedia - Social and Behavioral Sciences, 176(1998), 431-438. https://doi.org/10.1016/j.sbspro.2015.01.493

Brandmiller, C., Dumont, H., \& Becker, M. (2020). Teacher Perceptions of Learning Motivation and Classroom Behavior: The Role of Student Characteristics. Contemporary Educational Psychology, 63, 101893. https://doi.org/10.1016/j.cedpsych.2020.101893

Dong, C., Cao, S., \& Li, H. (2020). Young children's online learning during COVID-19 pandemic: Chinese parents' beliefs and attitudes. Children and Youth Services Review, 118(June), 105440. https://doi.org/10.1016/j.childyouth.2020.105440

Edriati, S., Anggraini, V., \& Siska, M. (2015). Efektivitas Model Jigsaw Disertai Penilaian Diskusi Untuk Meningkatkan Kemampuan Matematis Mahasiswa. Cakrawala Pendidikan, 1(2). https://doi.org/10.21831/cp.v2i2.4833

Elfeky, A. I. M., Masadeh, T. S. Y., \& Elbyaly, M. Y. H. (2020). Advance organizers in flipped classroom via elearning management system and the promotion of integrated science process skills. Thinking Skills and Creativity, 35. https://doi.org/10.1016/j.tsc.2019.100622

Eze, S. C., Chinedu-Eze, V. C., \& Bello, A. O. (2018). The utilisation of e-learning facilities in the educational delivery system of Nigeria: a study of M-University. International Journal of Educational Technology in Higher Education, 15(1). https://doi.org/10.1186/s41239-018-0116-Z

Fakhruddin, Z., Amzah, A., \& Nurchalis, N. F. (2019). Technology-Based Teaching Material Development Training for Pre-Service Teachers to Improve Students' Learning Outcomes. NOBEL: Journal of Literature and Language Teaching, 10(1), 87-102. https://doi.org/10.15642/nobel.2019.10.1.87-102

Ferri, F., Grifoni, P., \& Guzzo, T. (2020). Online Learning and Emergency Remote Teaching: Opportunities and Challenges in Emergency Situations. Societies, 10(4), 86. https://doi.org/10.3390/soc10040086

Garbin, C., Zhu, X., \& Marques, O. (2020). Dropout vs. batch normalization: an empirical study of their impact to deep learning. Multimedia Tools and Applications, 79(19-20), 2777-12815. https://doi.org/10.1007/s11042-019-08453-9

Gay, L. R., Mills, G. E., \& Airasian, P. W. (2012). Educational Research Competencies for Analysis and Applications (10th ed.). Pearson Education, Inc.

Ja'ashan, M. (2020). The Challenges and Prospects of Using E-learning among EFL Students in Bisha University. Arab World English Journal, 11(1), 124-137. https://doi.org/10.24093/awej/vol11no1.11

Khalil, Z. M. (2018). EFL Students' Perceptions towards Using Google Docs and Google Classroom as Online Collaborative Tools in Learning Grammar. Applied Linguistics Research Journal, 2(2), 33-48. 
https://doi.org/10.14744/alrj.2018.47955

Khan, M. A., Vivek, Nabi, M. K., Khojah, M., \& Tahir, M. (2021). Students’ Perception towards E-Learning During Covid-19 Pandemic In India: An Empirical Study. Sustainability, 13(1). https://doi.org/10.3390/su13010057

Lailiyah, \& Wulansari. (2017). Peningkatan Keterampilan Berbicara Melalui Metode Diskusi Kelompok Model Tanam Paksa Siswa Kelas X Pemasaran 1 SMK PGRI 2 Kediri. JP (Jurnal Pendidikan), 1(2), 166-173. https://doi.org/10.26740/jp.v1n2.p166-173.

Liando, N. V. F. (2012). Factors Affecting a Successful Language Learner. Indonesian JELT, 8(1). https://doi.org/10.25170\%2Fijelt.v8i1.89.

MacLachlan, M., Banes, D., Bell, D., Borg, J., Donnelly, B., Fembek, M., Ghosh, R., Gowran, R. J., Hannay, E., Hiscock, D., Hoogerwerf, E. J., Howe, T., Kohler, F., Layton, N., Long, S., Mannan, H., Mji, G., Odera Ongolo, T., Perry, K., ... Hooks, H. (2018). Assistive technology policy: a position paper from the first global research, innovation, and education on assistive technology (GREAT) summit. Disability and Rehabilitation: Assistive Technology, 13(5), 454-466. https://doi.org/10.1080/17483107.2018.1468496

Mailizar, M., Almanthari, A., Maulina, S., \& Bruce, S. (2020). Secondary School Mathematics Teachers' Views on E-learning Implementation Barriers during the COVID-19 Pandemic: The Case of Indonesia. Eurasia Journal of Mathematics, Science and Technology Education, 16(7), em1860. https://doi.org/10.29333/ejmste/8240

Márquez-García, M. J., Kirsch, W., \& Leite-Mendez, A. (2020). Learning and collaboration in pre-service teacher education: Narrative analysis in a service learning experience at Andalusian public schools. Teaching and Teacher Education, 96. https://doi.org/10.1016/j.tate.2020.103187

Mpungose, C. B. (2021). Lecturers' reflections on use of Zoom video conferencing technology for e-learning at a South African university in the context of coronavirus. African Identities. https://doi.org/10.1080/14725843.2021.1902268

Oostin, E. (2018). Family Influence on the Development of Children. Journal of Primary Education, 2(1). https://doi.org/10.22460/pej.v1i1.654

Parker, P. C., Perry, R. P., Hamm, J. M., Chipperfield, J. G., Dryden, R. P., \& Daniels, L. M. (2021). A motivation perspective on achievement appraisals, emotions, and performance in an online learning environment. International Journal of Educational Research, 108. https://doi.org/10.1016/j.ijer.2021.101772

Rahmat, I. (2020). Implementasi Andragogi Platform E-learning pada Blended Learning di Universitas Negeri Padang. Journal of Education Technology, 4(2), 133. https://doi.org/10.23887/jet.v4i2.24817

Ramkissoon, P., Belle, L. J., \& Bhurosy, T. (2020). Perceptions and experiences of students on the use of interactive online learning technologies in Mauritius. International Journal of Evaluation and Research in Education. https://doi.org/10.11591/ijere.v9i4.20692

Satyawan, I. M., Wahjoedi, \& Swadesi, I. K. I. (2021). The Effectiveness of Online Learning Methods During the Covid-19 Pandemic. Journal of Education Technology, 5(2), 191-199. https://doi.org/10.2991/assehr.k.210203.093

Soni, Hafid, Hayami, Fatma, Wenando, Amien, Fuad, Unik, \& Mukhtar. (2018). Optimalisasi Penggunaan Google Classroom, E-Learning \& Blended Learning sebagai Media Pembelajaran Bagi Guru dan Siswa di SMK Negeri 1 Bangkinang. Jurnal Pengabdian Untukmu Negeri, 21. https://doi.org/10.37859/jpumri.v2i1.361

Sophonhiranrak, S. (2021). Features, barriers, and influencing factors of mobile learning in higher education: A systematic review. Heliyon, 7(4). https://doi.org/10.1016/j.heliyon.2021.e06696

Stover, K., Yearta, L., \& Harris, C. (2016). Experiential Learning for Preservice Teachers: Digital Book Clubs With Third Graders. Journal of Digital Learning in Teacher Education, 32(1), 5-12. https://doi.org/10.1080/21532974.2015.1055013

Sunismi. (2015). Developing Guided Discovery Learning Materials Using Mathematics Mobile Learning Application As An Alternative Media For The Students Calculus II. Cakrawala Pendidikan, 34(5). https://doi.org/10.21831/cp.v3i3.7340

Weng, C., Otanga, S., Weng, A., \& Cox, J. (2018). Effects of interactivity in E-textbooks on 7th graders science learning and cognitive load. Computers \& Education, 120, 172-184. https://doi.org/10.1016/j.compedu.2018.02.008

Zhu, M., Bonk, C. J., \& Doo, M. Y. (2020). Self-directed learning in MOOCs: Exploring the relationships among motivation, self-monitoring, and self-management. Educational Technology Research and Development, 68(5), 2073-2093. https://doi.org/10.1007/s11423-020-09747-8 